\title{
P67 - Mothers restrict physical activity for children and teens asthmatics
}

\author{
Marco Correia Junior ${ }^{1}$, Fabianne Assis ${ }^{2}$, Décio Medeiros ${ }^{2}$, José Angelo Rizzo ${ }^{2}$, Silvia Sarinho ${ }^{2}$ Emanuel Sarinho ${ }^{2 *}$ \\ From 3rd Pediatric Allergy and Asthma Meeting (PAAM) \\ Athens, Greece. 17-19 October 2013
}

\section{Background}

Physical activities (PA) are important for children and adolescents, especially in asthmatics. A significant proportion of them are considered less active than their non-asthmatic peers and maternal health beliefs have been pointed as determinant factor.

\section{Aims and objectives}

To investigate if mothers impose limitations on physical activities of their asthmatic children, try to identify associated factors and ascertain if this attitude affects activities level.

\section{Methods}

In this cross sectional study were included 115 asthmatic children and adolescents 9 to 19 years old and their mothers. For the children, asthma severity, PA level and exercise induced bronchospasm (EIB) were evaluated. The mothers were investigated on their beliefs about PA in non-asthmatic and asthmatic children, if they imposed restrictions to their children PA, perception of exercise induced asthma and with an anxiety and depression questionnaire.

\section{Results}

Almost all the mothers reported that PA are important for children and adolescents. Despite this, 37\% (43/115) of them admitted that they imposed restrictions to their children PA. This attitude was associated with asthma severity and to maternal factors such as dyspnea perception after treadmill running, negative opinions about PA in asthmatics and anxiety. Despite this, their children were not less active than those from non restrictive mothers (odds ratio, 0.89 ; 95\% confidence interval, 0.41-1.95).

${ }^{2}$ Federal University of Pernambuco, Recife, Brazil

Full list of author information is available at the end of the article

\section{Conclusions}

A considerable proportion of mothers report to impose limitations on their children PA. Parental and caregiver beliefs and fears should be discussed about in order to avoid conflicts and negative attitudes that could discourage their children taking part in physical activities and sports.

\section{Authors' details \\ ${ }^{1}$ University of Pernambuco, Petrolina, Brazil. ${ }^{2}$ Federal University of \\ Pernambuco, Recife, Brazil.}

Published: 28 February 2014

doi:10.1186/2045-7022-4-S1-P122

Cite this article as: Correia Junior et al:: P67 - Mothers restrict physical activity for children and teens asthmatics. Clinical and Translational Allergy 2014 4(Suppl 1):P122.

\section{Submit your next manuscript to BioMed Central and take full advantage of: \\ - Convenient online submission \\ - Thorough peer review \\ - No space constraints or color figure charges \\ - Immediate publication on acceptance \\ - Inclusion in PubMed, CAS, Scopus and Google Scholar \\ - Research which is freely available for redistribution \\ Submit your manuscript at www.biomedcentral.com/submit}

